\title{
Contextos, reflexões e análises: Carolina Maria de Jesus e \\ o Quarto de Despejo
}

Jéssica Tomiko Araújo Mitsuuchi ${ }^{1}$

Resumo: Este artigo tem como objetivo contextualizar e discorrer acerca da obra Quarto de Despejo, de Carolina Maria de Jesus, aos futuros leitores e apreciadores deste diário. Negra, favelada e catadora de papel, a nossa personagem viveu na favela do Canindé, em São Paulo. A narrativa é iniciada em 1955, mas ela não se encerra no final da edição. Temos ainda hoje resquícios das temáticas que Carolina retrata em sua vida, que nos possibilitam uma reflexão profunda sobre a sociedade atual: a politicagem, a violência doméstica, o descaso com a população menos favorecida, preconceitos e a educação. As questões aqui levantadas devem ser pensadas e voltadas à formação do indivíduo como ser social e ativo, consciente da sua realidade, com perspectivas de possíveis mudanças transformadoras. A seguir, apresentaremos o contexto político, histórico e geográfico, uma breve biografia de Carolina, e a repercussão de sua obra e seus desdobramentos.

Palavras-chave: Quarto de Despejo; Carolina Maria de Jesus; Contexto.

Abstract: This article aims to contextualize and talk about the book Quarto de Despejo, by Carolina Maria de Jesus, to future readers and admirers of this diary. Black and a paper catcher, our character lived in the Canindé slum in São Paulo. The narrative begins in 1955, but it does not end at the end of the edition. We still have remnants of the themes that Carolina portrays in her life, which allow us to reflect deeply on the current society: politicking, domestic violence, neglect with the less favored population, prejudices and education. The issues raised here should be thought of and directed to the formation of the individual as a social and active being, aware of its reality, with prospects of possible transformative changes. Next, we will present the political, historical and geographic context, a brief biography of Carolina, the repercussion of her work and its unfolding.

Keywords: Quarto de Despejo; Carolina Maria de Jesus; Context.

${ }^{1}$ Graduanda do Curso de Pedagogia na Universidade Federal do Paraná. E-mail: jessicatomiko@gmail.com.

Revista Vernáculo n. ${ }^{\circ} 41$ - primeiro semestre /2018

ISSN 2317-4021 


\section{Quarto de Despejo ${ }^{2}$ : de 1955 aos dias atuais}

Carolina Maria de Jesus nos apresenta a realidade da favela do Canindé, São Paulo, entre os anos de 1955 e 1960, por meio de seu diário íntimo, caracterizado pela sua autobiografia, memória e testemunho ${ }^{3}$. Sua narrativa explicita vários momentos temporais, que relacionam reflexões da própria escrita e do seu passado. Isso é feito cronologicamente, com a descrição da vida da favelada e dos espaços ao seu redor, mesmo que se repitam com frequência. Também podemos observar algumas rupturas entre os períodos de relato, como a ausência de registros nos anos de 1956 e 1957, justificada no início do ano seguinte como a perspectiva da desvalorização e perda de tempo na produção do diário.

Nossa personagem utiliza a palavra como instrumento de voz e de denúncia acerca das mazelas que viveu e, ao agir e romper com o determinismo social imposto pela natureza ao que se refere à convivência em sociedade permitido pela palavra e tudo o que se relaciona a ela, descobre-se como capaz de escrever a própria história, detendo o poder de ressignificar sua existência e tornar-se sujeito

2 JESUS, Carolina Maria de. Quarto de despejo: Diário de uma Favelada. São Paulo: Ática, 1995. 173p.

${ }^{3}$ SOUSA, Germana Henrique P. de. Memória, Autobiografia e Diário Íntimo: Carolina Maria de Jesus: Escrita íntima e narrativa de Vida. Originada na Tese de Doutorado, UnB. Quadrant, Montpellier, v. 24, p. 299-313, 2007. Disponível em http://repositorio.unb.br/bitstream/10482/9169/1/CAPITULO_MemoriaAutobiografia Diario.pdf. Acesso em 17/05/2015.

Revista Vernáculo n. ${ }^{\circ} 41$ - primeiro semestre $/ 2018$

ISSN 2317-4021 
político e socialmente - além do pensamento de ascensão social por meio da divulgação das suas obras.

A oportunidade da publicação do diário emerge com o jornalista Audálio Dantas, em 1958, que, vivenciando uma fase da cultura de comunicação de massas no Brasil, tornava público o jornalismo de denúncia pela Folha da Noite ${ }^{4}$. Ao ser incumbido de realizar uma reportagem sobre a favela que se estabelecia na beira do rio Tietê, se depara com "uns vinte cadernos encardidos que Carolina guardava em seu barraco. Li, e logo vi: repórter nenhum, escritor nenhum poderia escrever melhor aquela história - a visão de dentro da favela", Esse fato serve de motivação para que Carolina retome a narrativa do cotidiano e transforme seu editor em personagem Audálio é uma espécie de narratário (a quem o narrador dirige o seu discurso, e não deve ser confundido com o leitor), mas também um personagem importante nessa quase ficcionalização que Carolina faz de sua história ${ }^{6}$.

Porém, próximo ao final da história, a autora se depara com vários conflitos em relação à publicação, e expõe sua fúria contra

${ }^{4}$ MEIHY, José Carlos Sebe Bom. Carolina Maria de Jesus: emblema do silêncio. Revista USP, São Paulo (37): 82-91, Março/Maio 1998. Disponível em <http://www.usp.br/revistausp/37/08-josecarlos.pdf>. Acesso em 17/05/2015.

5 Apud JESUS, Carolina Maria de. Quarto de despejo: Diário de uma Favelada. São Paulo: Ática, 1995. 173p. p. 3.

${ }^{6}$ SOUSA, Germana Henrique P. de. Memória, Autobiografia e Diário Íntimo: Carolina Maria de Jesus: Escrita íntima e narrativa de Vida. Originada na Tese de Doutorado, UnB. Quadrant, Montpellier, v. 24, p. 299-313, 2007. Disponível em http://repositorio.unb.br/bitstream/10482/9169/1/CAPITULO_MemoriaAutobiografia Diario.pdf. Acesso em: 17/05/2015.

Revista Vernáculo n. ${ }^{\circ} 41$ - primeiro semestre /2018

ISSN 2317-4021 
Dantas: "Se ele não prendesse o meu livro eu enviava os manuscritos para os Estados Unidos e já estava socegada" (p. 109). Carolina chega a enviar sua obra para os Estados Unidos, mas os cadernos retornaram do The Reader's Digest": “A pior bofetada para quem escreve é a devolução de sua obra" (p. 125).

É essa a força que estrutura o texto de Carolina e a leva a descrever a realidade em que vive tecida com elementos diferentes da cultura dominante (branca, elitizada e letrada). E, mais que uma denúncia da miséria em que vive, o exercício da voz por meio da literatura permite a Carolina a criação de um mundo impossível, de fantasias, uma vez que ela pontua que "É preciso criar este ambiente de fantasia, para esquecer que estou na favela. [...] As horas que sou feliz é quando estou residindo nos castelos imaginarios" (p. 52). De acordo com Meihy ${ }^{8}$, advoga-se assim a existência e representatividade da cultura popular, ao abrir espaço para a suposição de que pobre, semialfabetizado, marginalizado também merece seu lugar literário na cena nacional. Corroboram essa perspectiva as ideias de Zinani ${ }^{9}$, que tece considerações acerca da literatura marginal, construída com uma

${ }^{7}$ Conhecida popularmente no Brasil como SELEÇÕES, apresenta reportagens sobre saúde, beleza, meio ambiente, cotidiano; bem como curiosidades, relatos de vida, humor, diversão, pesquisas e atualidades (Mundo das Marcas, 2006).

${ }^{8}$ MEIHY, José Carlos Sebe Bom. Carolina Maria de Jesus: emblema do silêncio. Revista USP, São Paulo (37): 82-91, Março/Maio 1998. Disponível em <http://www.usp.br/revistausp/37/08-josecarlos.pdf>. Acesso em 17/05/2015.

${ }^{9}$ ZINANI, Cecil Jeanine Albert. Produção literária feminina: um caso de literatura marginal. ANTARES, v. 6, n. 12, p. 183-195, jul./dez. 2014. Disponível em <www.ucs.br/etc/revistas/index.php/antares/article/viewFile/3059/1814>. Acesso em $15 / 08 / 2017$.

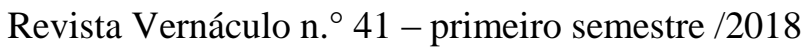

ISSN 2317-4021 
linguagem própria, e salienta o confronto entre a expressão de uma minoria e a arte canônica da classe dominante. Desse modo, define de forma assertiva a obra evidenciada neste texto, uma vez que literatura marginal é "aquela produzida por afrodescendentes e por mulheres, na medida em que buscam modalidades de representação próprias" ${ }^{\prime 10}$ - tal qual Carolina e sua trajetória na favela do Canindé.

Em relação à produção autobiográfica em forma de diário, Santos $^{11}$ remete o início deste gênero ao século XVII, com o advento da burguesia e a problematização da construção do eu, além do crescente acesso das mulheres ao mundo letrado. Representando o confronto com a produção masculina, a literatura feminina, "como tradução de um grupo subalterno, marginal, cuja posição na sociedade sempre foi minoritária, transformou-se em possibilidade de afirmação desse grupo, de as mulheres tornarem-se sujeitos do discurso" ${ }^{\text {"12 }}$.

A narradora evoca acontecimentos e espaços representativos de um momento da história do Brasil. Santos ${ }^{13}$ discorre que as autobiografias das mulheres representam "uma fonte rica de

${ }^{10}$ Idem, p. 185.

11 SANTOS, Marcela Ernesto dos. Autobiografia feminina: a identidade e o preconceito nas memórias de Carolina Maria de Jesus e Maya Angelou. Revista Iluminart, IFSP, v. 1, n. 4, Sertãozinho, abril 2010.. p. 12-20. Disponível em <https://repositorio.unesp.br/handle/11449/94065>. Acesso em 10/08/2017.

12 ZINANI, Cecil Jeanine Albert. Produção literária feminina: um caso de literatura marginal. ANTARES, v. 6, n. 12, p. 183-195, jul./dez. 2014. p. 189. Disponível em <www.ucs.br/etc/revistas/index.php/antares/article/viewFile/3059/1814>. Acesso em $15 / 08 / 2017$.

13 SANTOS, Marcela Ernesto dos. Autobiografia feminina: a identidade e o preconceito nas memórias de Carolina Maria de Jesus e Maya Angelou. Revista Iluminart, IFSP, v. 1, n. 4, Sertãozinho, abril 2010. p. 12-20. p. 13. Disponível em <https://repositorio.unesp.br/handle/11449/94065>. Acesso em 10/08/2017.

Revista Vernáculo n. ${ }^{\circ} 41$ - primeiro semestre /2018

ISSN 2317-4021 
informações, pois revelam os sentimentos e as frustrações vividas naquele tempo". Dessa forma, para compreendermos de modo amplo tal narrativa, precisamos contextualizá-la e situá-la no espaço político, histórico e geográfico. Nessa perspectiva, Meihy $^{14}$ pontua que durante este período da obra em questão, a sociedade brasileira passava por uma intensa experiência democrática, que se inicia com a superação do Estado Novo (1937-45) e se encerra com a instalação da Ditadura Militar (1964). Carolina demonstra ser uma pessoa extremamente atualizada em relação ao que se passa na vida política do país, o que se comprova pelas constantes referências aos políticos em destaque na época, como Carlos Lacerda, Jânio Quadros, Adhemar de Barros e Juscelino Kubitschek. A exploração da boa-fé do povo pelos políticos na época de eleições, as visitas dos candidatos à favela, os pequenos agrados e as promessas não cumpridas são registradas pela narradora de forma crítica e consciente:

[...] Quando eu era menina o meu sonho era ser homem para defender o Brasil porque eu lia a Historia do Brasil e ficava sabendo que existia guerra. Só lia os nomes masculinos como defensor da pátria. [...] Quando o arco-iris surgia eu ia correndo na sua direção. Mas o arco-iris estava sempre distanciando. Igual os politicos distante do povo. Eu cançava e sentava. Depois começava a chorar. Mas o povo não deve cançar. Não deve chorar. Deve lutar para melhorar o Brasil para os

${ }^{14}$ MEIHY, José Carlos Sebe Bom. Carolina Maria de Jesus: emblema do silêncio. Revista USP, São Paulo (37): 82-91, Março/Maio 1998. Disponível em <http://www.usp.br/revistausp/37/08-josecarlos.pdf>. Acesso em 17/05/2015.

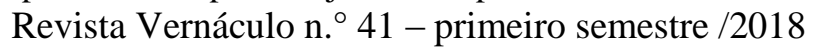

ISSN 2317-4021 
nossos filhos não sofrer o que estamos sofrendo (p. 48).

[...] Quando um politico diz nos seus discursos que está ao lado do povo, que visa incluir-se na politica para melhorar as nossas condições de vida pedindo o nosso voto prometendo congelar os preços, já está ciente que abordando este grave problema ele vence as urnas. Depois divorcia-se do povo. Olha o povo com os olhos semi-cerrados. Com um orgulho que fere a nossa sensibilidade (p. 34).

Nas ruas só se vê cédulas pelo chão. Fico pensando nos desperdícios que as eleições acarreta no Brasil. $\mathrm{Eu}$ achei mais difícil votar do que tirar o titulo (p. 110).

No que diz respeito ao aspecto histórico e geográfico, podemos relacionar com o surgimento das favelas no Brasil após a abolição da escravatura, onde os negros, então livres, passaram a se aglomerar em espaços pequenos, que agregaram também outros grupos marginalizados e pessoas que não conseguiram sobreviver nos centros urbanos, sendo o desenvolvimento da economia brasileira um dos fatores agravantes para esse panorama durante o século XX. Os anos de 1950 e 1960, contudo, representaram para o imaginário nacional um tempo de euforia, idealizando um período de desenvolvimento e intensas transformações no país - o que omitia o contraste com o ideário de modernização: a miséria urbana, os pobres, os favelados.

Santos e Borges ${ }^{15}$ trazem o avanço das favelas da cidade de São Paulo entre 1940, com a favela do Oratório, até o final de 1950,

15 SANTOS, Lara Gabriella Alves dos; BORGES, Valdeci Rezende. Quarto de Despejo: o espaço na obra de Carolina de Jesus. Universidade Federal de Goiás. Anais do SILEL, Volume 3, Número 1. Uberlândia: EDUFU, 2013. Disponível em

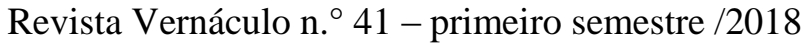


com aproximadamente 140 núcleos. A favela do Canindé, cenário em que a nossa personagem vive, teve sua origem no mandato do governador Adhemar de Barros, que "limpou" o centro da cidade ao retirar moradores de rua e "alojá-los" nas margens do rio Tietê, em meio a lixos e urubus, reforçando a desigualdade fundiária rural e urbana. Eram cerca de 180 barracos e uma torneira, citada em quase toda a narrativa. É relevante a percepção da favela não apenas caracterizada por problemas adversos, mas como também um espaço multicultural, como no caso de Carolina e os personagens envolvidos na trama.

No entanto, percebemos também que a relação territórioidentidade é muitas vezes conflituosa, ocasionando até mesmo expressivo repúdio pelo mesmo: Carolina rejeitava qualquer ligação emotiva, qualquer traço que a identificasse com a favela. Ao comentar sobre suas frequentes idas para buscar água, a autora afirma ter "pavor destas mulheres da favela" (p. 12), denotando com isso certo distanciamento e certo grau de não identificação com a própria comunidade. Zinani e Poleso ${ }^{16}$ abordam esse apontamento ao discorrer que a construção da identidade do eu e da identidade cultural são marcadas pela diferença e envoltas por certa negação: a autora não se

<http://www.ileel.ufu.br/anaisdosilel/wpcontent/uploads/2014/04/silel2013_1545.pdf> . Acesso em 13/04/2015.

${ }^{16}$ ZINANI, Cecil Jeanine Albert; POLESO, Natalia Borges. Da margem: a mulher escritora e a história da literatura. MÉTIS: história e cultura, v. 9, n. 18, p. 99-112, jul./dez. $2010 . \quad$ Disponível em <www.ucs.br/etc/revistas/index.php/metis/article/viewFile/998/1054>. Acesso em $15 / 08 / 2017$.

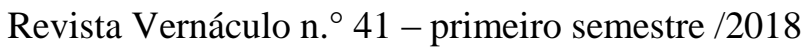

ISSN 2317-4021 
reconhece como uma mulher de favela. "Nunca feri ninguém. Tenho muito senso! Não quero ter processos. O meu registro geral é 845.936" (p. 16). Deste modo, Carolina define-se como cidadã, como se o número a tornasse parte de uma sociedade, que certamente não é a da favela. E, nesse contexto, surge a expressão que dá título ao diário:

[...] Eu classifico São Paulo assim: O Palacio, é a sala de visita. A Prefeitura é a sala de jantar e a cidade é o jardim. E a favela é o quintal onde jogam os lixos (p. 28).

Quando estou na cidade tenho a impressão de que estou na sala de visita com seus lustres de cristais, seus tapetes de viludos, almofadas de sitim. E quando estou na favela tenho a impressão que sou um objeto fora de uso, digno de estar num quarto de despejo (p. 33).

Nesse sentido, a nossa personagem relata com desprezo a convivência amargurada com as pessoas que ali residem, relatando eventos e registrando cada movimento que acontece na favela do Canindé. Ficam evidentes elementos que a seguem durante a narrativa, tais como a violência física, verbal, infantil e doméstica, a prostituição, o alcoolismo, intrigas e a inveja - uma extrema situação de vulnerabilidade. Os trechos a seguir apresentam algumas dessas fortes características, ao repúdio de Carolina:

Depois que a favela superlotou-se de nortistas tem mais intriga. Mais polemica e mais distrações. A favela ficou quente igual a pimenta. Fiquei na rua até nove horas pra prestar atenção nos movimentos da favela. Para ver como é que o povo age a noite. [...] Não interfiro-me porque não gosto de polemica. [...] Revista Vernáculo n. ${ }^{\circ} 41$ - primeiro semestre /2018 
A conversa não me interessava, mas eu fiquei (p. $67)$.

[...] E o pior na favela é o que as crianças presenciam. Todas crianças da favela sabem como é o corpo de uma mulher. Porque quando os casais que se embriagam brigam, a mulher, para não apanhar sai nua para a rua. Quando começa as brigas os favelados deixam seus afazeres para presenciar os bate-fundos. [...]... A favela é o quarto das surpresas (p. 40).

Eu já estou na favela há 11 anos e tenho nojo de presenciar estas cenas (p. 69).

Entretanto, algo que também chama a atenção são as contradições apresentadas a falas como as citadas anteriormente, como "A Dorça foi lavar roupas e ficamos conversando sobre as poucavergonhas que ocorrem aqui na favela. Falamos da Zefa que apanha todos os dias. Falei das mulheres que não trabalham e estão sempre com dinheiro" (p. 115) e "Quando eu dirigia-me para casa vi varias pessoas olhando na mesma direção. Pensei: é briga! Corri para ver o que era" (p. 140). Outro aspecto que vem de encontro ao que ela critica ferozmente refere-se ao consumo de álcool, uma vez que afirma não beber porque não gosta e pede para que a parabenizem, e noutro momento descreve: "Serviram quentão e vinho. Eu bebi duas xícaras. Fiquei alegre. [...] Quando eu percebi que o álcool estava desviando o meu senso eu fui deitar. Antes de deitar dei uma surra no João, porque ele está muito malcriado" (p. 66).

Carolina Maria de Jesus é frequentemente retratada como negra, mulher, pobre, semianalfabeta e mãe de três filhos de pais diferentes, de tal forma que essas características causam certa

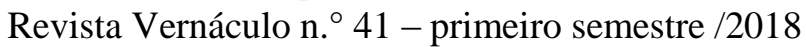


estranheza, por ter escrito um diário que repercutiu no mundo todo. Nasceu em 1914, e sua forma de escrita impressiona pelo fato de ter estudado apenas dois anos em uma escola espírita, na cidade de Sacramento, Minas Gerais. Toda sua educação formal na leitura e escrita advém deste pouco tempo de estudos. Sua infância e adolescência não foram fáceis, nem propícias a uma formação escolar, uma vez que necessitava do trabalho para sobreviver. No entanto, vemos em um trecho o almejo por um bom futuro, além da formação de caráter: "[a mãe] Queria que eu estudasse para professora. Foi as contigencias da vida que lhe impossibilitou concretizar o seu sonho. Mas ela formou o meu caráter, ensinando-me a gostar dos humildes e dos fracos” (p. 42). Logo, é frequente a sua inconformidade diante de sua condição, ao dizer que "Parece que eu vim ao mundo predestinada a catar. Só não cato a felicidade” (p. 72).

A ida para a favela do Canindé ocorre em 1948, visando melhores condições de vida; é onde nasce o primeiro filho, João José, fruto do relacionamento com um marinheiro português, que a abandona. Em 1950, nasce o segundo filho, José Carlos, após relacionamento com um espanhol; e três anos depois, Vera Eunice, com o dono de uma fábrica e comerciante, cuja identidade nunca foi revelada por Carolina e presente nos últimos anos do diário.

Algo que percebemos durante todo o relato é a afetividade que Carolina tem com seus filhos; apesar dos mesmos não serem tão obedientes, ela os defende como pode dos vizinhos que reclamam, 
xingam e até batem neles. Tal afetuosidade é recíproca nas crianças, que almejam a mudança de vida e bendizem a mãe que têm, lhe prometendo casa de tijolos e a defendendo das vizinhas que a agridem verbalmente e lhe fazem maldades.

Quanto ao comportamento dos filhos, vemos que Vera Eunice gosta de sapatos novos, não gosta de ficar sozinha em casa, acompanhando Carolina, e tem pavor de morar na favela. José Carlos aparenta ser responsável, apesar de chegar tarde quase todos os dias e chamar a atenção do tenente em relação à propensão delinquente da vida na favela. Nesse sentido, há a descrição de que Carolina busca, em 1952, a possibilidade de internar seus filhos no Juizado - e isso não acontece apenas uma vez -, mas é alertada que caso fossem internados se tornariam ladrões. Já João José apresenta alguns problemas, uma vez que a autora descreve um processo em que este é acusado de ter tentado violentar uma menina de dois anos de idade e passa por um interrogatório, que relata os "prazeres sexuais" do garoto e se os havia feito na menina. Isso gera grande preocupação à sua mãe, que o priva de sair de casa sozinho ou brincar com outras crianças.

Não deixo o João sair. Ele passa o dia lendo. Ele conversa comigo e eu vou revelando as coisas inconvinientes que existe no mundo. Já que o meu filho já sabe como é o mundo, a linguagem infantil entre nós acabou-se. [...] Disse-lhe que enquanto nós residirmos aqui na favela ele não há de brincar com mais ninguém. Antes eu falava e ele revoltava. Agora eu falo e ele ouve. Eu pretendia conversar com o meu filho as coisas sérias da vida só quando

Revista Vernáculo n. ${ }^{\circ} 41$ - primeiro semestre /2018

ISSN 2317-4021 
ele atingisse a maioridade. Mas quem reside na favela não tem quadra e vida. Não tem infância, juventude e maturidade. O meu filho, com 11 anos já quer mulher. Expliquei-lhe que ele precisa tirar o diploma de grupo. E estudar depois, que o curso primário é muito pouco (p. 82).

No entanto, a nossa narradora ainda enfrenta dificuldades com o filho, e age de forma negativa e exagerada à prática de leitura do mesmo, que era em sua grande maioria gibis: "Ele passa o dia lendo Gibi e não presta atenção em nada. Vive pensando que é o homem invisível, Mandraque e outras porcarias. [...] Depois dei-lhe uma surra. Com uma vara e uma correia. E rasguei-lhe os Gibis desgraçados. Tipo de leitura que eu detesto" (p. 112; 117). Dessa forma, fica uma questão para refletirmos: Que empecilhos Carolina tinha contra a leitura de gibis e a imaginação fantasiosa? Relembramos que ela própria imaginava-se em outros mundos ficcionais e valorizava a educação, obrigando seus filhos a irem para a escola da comunidade e enfatizando a ideia de "ser alguém" por meio do letramento.

Mesmo na cidade, e em meio à pobreza, Carolina conseguiu se distinguir tanto por ser mulher bonita como por saber ler e escrever estes últimos como forma de superioridade aos favelados, tendo em vista que não faz parte do contexto em questão. Ficam em grande evidência seus esforços nestas práticas realizadas com persistência em diversos momentos do dia e da noite - o que chama bastante atenção de quem a observa, gerando até mesmo comentários como “- Nunca vi uma preta gostar tanto de ler livros como você” (p. 23). Ela discorre que

Revista Vernáculo n. ${ }^{\circ} 41$ - primeiro semestre /2018

ISSN 2317-4021 
todos têm um ideal, sendo o dela o gosto por ler, que o livro é a melhor invenção do homem, e que ainda prefere escrever a discutir. Quando questionada sobre o que escreve, responde: "Todas as lambanças que pratica os favelados, estes projetos de gente humana" (p. 20). Ou ainda, quando enfrentada, desabafa e ameaça: "Vou escrever um livro referente a favela. Hei de citar tudo o que aqui se passa. E tudo o que vocês me fazem. Eu quero escrever o livro, e vocês com estas cenas desagradaveis me fornecem os argumentos" (p. 17). Além disso, vê em sua produção autobiográfica uma oportunidade de ganhar dinheiro e sair da favela - um dos maiores sonhos de Carolina.

A respeito de criar sozinha seus três filhos, Carolina defende sua posição ao constatar que são poucas as famílias em que marido e esposa são educados entre si e com os filhos, e que na maioria dos relatos há a violência familiar, brigas, "palavras de baixo calão". Ela demonstra ser solitária, apresentando trechos como no começo da narrativa, que representam a espera por alguém que não vem, e "como é pungente a condição de mulher sozinha sem um homem no lar" (p. 19). Em determinado sentido, ser solteira assume uma conotação positiva, porque lhe possibilita maior independência e, inclusive, a liberdade de permanecer escrevendo até tarde da noite. Contudo, encontramos novamente contradições: ela se envolve com o senhor Manoel e o cigano Raimundo.

O senhor Manoel é um homem distinto, trabalha, mora na favela há nove anos e sempre quis se casar com Carolina, que sente 
saudades dele e confessa: "Olho e penso: este homem não serve para mim. Parece um ator que vai entrar em cena. [...] Mas quando eu estou deitada com ele, acho que ele me serve" (p. 119). Em relação a Raimundo, a nossa autora fazia uma crítica ferrenha aos ciganos, os chamando de nojentos e os colocando em uma classe inferior aos favelados. No entanto, ao se deparar com o cigano parecido com Castro Alves, todas essas afrontas são deixadas de lado por existir uma "atração espiritual" entre eles: "No inicio receei a sua amisade. E agora, se ela medrar para mim será um prazer. Se regredir, eu vou sofrer. Se eu pudesse ligar-me a ele! [...] Que emoção que eu sentia vendo-o ao meu lado" (p. 134). O retorno de sua concepção da sordidez cigana é dado ao perceber que o seu amado tira proveito de sua beleza, iludindo as mulheres pra conseguir o que quer. Logo, Carolina recorre novamente ao senhor Manoel como fonte de afeto e carinho, mas dispara:

- Eu tenho muito serviço. Não posso preocupar com homens. Meu ideal é comprar uma casa decente para os meus filhos. Eu, nunca tive sorte com homens. Por isso não amei ninguém. Os homens que passaram na minha vida só arranjaram complicações para mim. Filhos para eu criá-los (p. 166).

A última relação relatada é com o pai de Vera Eunice, quando este aparece na enfermidade de sua filha. Ele é rico e tem apenas suas iniciais reveladas, como forma de vingança de Carolina por ele não ter depositado o dinheiro de Vera intermediado pelo Juizado, o senhor J. A. M. V. No trecho a seguir, evidenciam-se claramente as intenções deste: "Ele mandou os filhos comprar doces para nós ficarmos sozinhos. Tem Revista Vernáculo n. ${ }^{\circ} 41$ - primeiro semestre $/ 2018$ 
hora que eu tenho desgosto de ser mulher. Dei graças a Deus quando ele despediu-se" (p. 156), além de ser comentado que ele só aparece quando a personagem ganha destaque nos jornais.

Ela conviveu com o preconceito racial lado a lado, mas tinha consciência de que era semelhante aos outros mesmo que dissessem o contrário. Ela reforçava a ideia de que "Deus criou todas as raças na mesma epoca. Se criasse os negros depois dos brancos, aí os brancos podia revoltar-se" (p. 108), além de aceitar suas características: “[...] adoro a minha pele negra, e o meu cabelo rústico. [...] Se é que existe reincarnações, eu quero voltar sempre preta. [...] A natureza não seleciona ninguém" (p. 58). No entanto, às vezes usa da sua cor para fazer comparações negativas, como "Comeram e não aludiram a cor negra do feijão. Porque negra é a nossa vida. Negro é tudo que nos rodeia" (p. 39) e "Preta é a minha pele. Preto é o lugar onde eu moro" (p. 147).

Outro agravante, talvez o mais exposto e sofrido na dura realidade de Carolina, tem relação à cor amarela: o limite da fome que passa do insuportável. Esse é um elemento fortemente presente no cotidiano da favela, e nossa narradora enfatiza incansavelmente a busca por doações, a falta de dinheiro para comprar comida, o auxílio de algumas vizinhas e até mesmo a procura em lixos pelo alimento: "Para mim o mundo em vez de evoluir está retornando a primitividade" ( $p$. 34). Nesse aspecto, o efeito da saciação da fome é descrito entusiasticamente:

Revista Vernáculo n. ${ }^{\circ} 41$ - primeiro semestre /2018

ISSN $2317-4021$ 
A comida no estomago é como o combustível das maquinas. Passei a trabalhar mais depressa. O meu corpo deixou de pesar. Comecei a andar mais depressa. [...] Comecei a sorrir como se estivesse presenciado um lindo espetáculo. E haverá espetáculo mais lindo do que ter o que comer? Parece que eu estava comendo pela primeira vez na minha vida (p. 40).

Pela falta de alimento e pelo custo da vida, Carolina evoca o sentimento de suicídio como solução rápida para o sofrimento. Por vezes registra sua perda de interesse pela existência, mas não tem coragem para concretizar o ato contra sua vida. O ponto de desespero que podemos perceber é na passagem a seguir:

Hoje não temos nada para comer. Queria convidar os filhos para suicidar-nos. Desisti. Olhei meus filhos e fiquei com dó. Eles estão cheios de vida. Quem vive, precisa comer. Fiquei nervosa, pensando: será que Deus esqueceu-me? Será que ele ficou de mal comigo? (p. 153).

Carolina recorria a quem podia para ajudá-la nessas situações, como a diretora da escola de seus filhos e, mais frequentemente, o Centro Espírita Divino Mestre. Nessa perspectiva, a religião da narradora não é deixada clara, mas, apesar de ir ao referido centro, ela possuía conhecimentos católicos, como a Páscoa e a Bíblia, além da fé em um Deus onipotente e de alguns preceitos da Igreja: "Disse-lhe para ela ter paciência e esperar que Jesus Cristo vem ao mundo para julgar os bons e os maus" (p. 123). Outros conhecimentos gerais também são perceptíveis para alguém com tão pouca formação acadêmica formal, 
tal qual a ideia do cavalo de Troia e a perseguição de Cesar contra os cristãos - tudo isso deve ter sido absorvido com propriedade nos livros que Carolina encontrou em seu caminho.

Durante toda a sua vida, Carolina teve uma saúde fragilizada. Feridas na perna, dores de cabeça, mal-estares prolongados e algumas intoxicações por comer alimentos estragados, apesar dos cuidados. O descaso com a saúde da população da favela era tamanho que o serviço de Saúde apresentou filmes sobre a doença caramujo ${ }^{17}$, mas não forneceu os medicamentos, já que a doença era difícil de curar.

Carolina Maria de Jesus morre aos 63 anos no dia 13 de fevereiro de 1977, vítima de uma crise de asma, em Parelheiros, São Paulo.

Após a publicação do Quarto de Despejo, em 1960, Carolina tornou-se uma heroína popular. Com as reportagens a seu respeito feitas por Audálio Dantas, e lançada com uma forte campanha de marketing, nossa personagem-escritora foi elevada ao sucesso, com mais de cem mil cópias produzidas. Deu entrevistas nas rádios e na televisão, participou de feiras de livros, inauguração de escolas, ficou conhecida em todo o Brasil, viajou para outros países e teve sua obra traduzida para outros idiomas. Dessa forma, por um breve momento, com

${ }^{17}$ Provavelmente seria a Esquistossomose, doença causada pelo Schistosoma mansoni, parasita que tem no homem seu hospedeiro definitivo, mas que necessita de caramujos de água doce como hospedeiros intermediários para desenvolver seu ciclo evolutivo. Tem manifestações clínicas como coceiras e dermatites, febre, tosse, diarreia, enjoos, vômitos e emagrecimento - alguns sintomas que Carolina relata apresentar (Via Dr. Drauzio Varella, 2011).

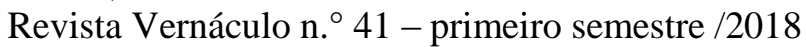

ISSN 2317-4021 
prestígio na mídia e uma situação financeira relativamente estável, adquiriu a sonhada "casa de alvenaria" em Santana, bairro de classe média paulistano. Depois, mudou-se para a Chácara Coração de Jesus, no bairro de Parelheiros, periferia da Zona Sul de São Paulo, onde faleceu, longe dos holofotes.

\section{Segundo Eliana Castro,}

Carolina não corresponde aos estereótipos e sempre surpreende. Negra, espera-se que seja humilde, mas não é. Mulher, espera-se que seja submissa, mas não é. Semianalfabeta, espera-se que seja ignorante, mas não é. E não sendo o que se espera dela, é rejeitada como pessoa pela sociedade e incompreendida com escritora. ${ }^{18}$

O tempo, que fascina os homens e que não pode ser domado, se encarregou de dar voz à catadora de lixo. Cumprindo seu papel de intelectual ao retratar o ambiente em que vivia, suas mazelas e dificuldades, bem como a dos moradores da favela do Canindé, Carolina Maria de Jesus nos oferece importantes informações a respeito da sociedade brasileira, tornando seus registros pessoais fontes documentais de grande importância historiográfica.

${ }^{18}$ Apud SANTOS, Gláucia. A intelectualidade de Carolina Maria de Jesus por meio de sua obra "Quarto de Despejo". Centro Universitário de Patos de Minas. Pergaminho (5): 59-68, dez. 2014. Disponível em <http://pergaminho.unipam.edu.br/documents/43440/599489/A+intelectualidade+de+ Carolina++Maria+de+Jesus+por+meio+de+sua+obra++_Quarto+de+Despejo_.pdf $>$. Acesso em 18/04/2015.

Revista Vernáculo n. ${ }^{\circ} 41$ - primeiro semestre $/ 2018$

ISSN 2317-4021 
Meihy ${ }^{19}$ pontua que as pessoas que viveram no período da publicação não se esqueceram do impacto que a obra causou. Mas, “coerente com o 'apagamento' da memória da contracultura, o livro de Carolina escorreu pela vala do esquecimento como se não tivesse tido importância singular em nossa história da cultura"20: Carolina é o contraste da sociedade que se erguia. Zinani e Poleso ${ }^{21}$ afirmam que

[...] muito da produção feminina escrita, tanto literária quanto crítica, política ou social pode ter-se perdido, especialmente pela não valorização desses trabalhos, afinal, o contexto da produção é uma sociedade patriarcal dominante que não considera a mulher como cidadã dotada de pensamentos, vontades e direitos, negando-lhe, também, uma identidade intelectual.

\section{Zinani $^{22}$ comenta que}

A conquista de um novo espaço começou a tornar-se viável, quando aquelas vozes silenciadas passaram a reivindicar educação, cidadania, expressão. Falando

${ }^{19}$ MEIHY, José Carlos Sebe Bom. Carolina Maria de Jesus: emblema do silêncio. Revista USP, São Paulo (37): 82-91, Março/Maio 1998. Disponível em <http://www.usp.br/revistausp/37/08-josecarlos.pdf>. Acesso em 17/05/2015.

${ }^{20}$ Idem, p. 85.

${ }^{21}$ ZINANI, Cecil Jeanine Albert; POLESO, Natalia Borges. Da margem: a mulher escritora e a história da literatura. MÉTIS: história e cultura, v. 9, n. 18, p. 99-112, jul./dez. $2010 . \quad 102 . \quad$ p. $\quad 100$ Disponível em <www.ucs.br/etc/revistas/index.php/metis/article/viewFile/998/1054>. Acesso em $15 / 08 / 2017$.

${ }^{22}$ ZINANI, Cecil Jeanine Albert. Produção literária feminina: um caso de literatura marginal. ANTARES, v. 6, n. 12, p. 183-195, jul./dez. 2014. p. 193. Disponível em <www.ucs.br/etc/revistas/index.php/antares/article/viewFile/3059/1814>. Acesso em $15 / 08 / 2017$.

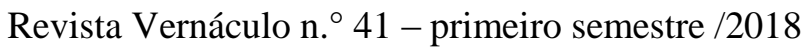

ISSN 2317-4021 
a partir de seu mundo, de suas experiências, as mulheres adentraram no fazer literário, tornando-se presença relevante, mas ainda com pouca densidade, uma vez que o reconhecimento e a validação acadêmica não estão consolidados.

Neste sentido, a glória da obra foi ofuscada pela burguesia no tratamento crítico-literário e historiográfico. A estranheza da sociedade sobre a escritora é mútua, pois de um lado estão os favelados que nunca tinham visto algo semelhante, e do outro, a elite letrada que não a aceita porque Carolina representa tudo o que não deveria ser: mulher, negra e marginalizada, legitimou-se por meio da escrita de sua realidade e pela transição para um patamar elevado de vida.

A nova realidade de Carolina é relatada em Casa de Alvenaria $^{23}$, publicado em 1961, e a apresentação de Audálio Dantas logo revela que a obra é

[...] depoimento tão importante quanto 'Quarto do Despejo', mesmo sem o tom dramático da miséria favelada. [...] porque nele há um pouco de alegria, há o deslumbramento da descoberta, há a felicidade do estômago satisfeito, há a perplexidade diante de pessoas e coisas diferentes e uma amarga constatação: a miséria existe também na alvenaria, em formas as mais diversas ${ }^{24}$.

23 JESUS, Carolina Maria de. Casa de Alvenaria: Diário de uma ex-favelada. São Paulo: Francisco Alves, 1961. 183p.

${ }^{24}$ Apud JESUS, Carolina Maria de. Casa de Alvenaria: Diário de uma ex-favelada. São Paulo: Francisco Alves, 1961. 183p. p. 7.

Revista Vernáculo n. ${ }^{\circ} 41$ - primeiro semestre $/ 2018$

ISSN 2317-4021 
$\mathrm{Na}$ "sala de visitas", a nossa personagem ainda se sentia ameaçada e receosa, apesar do conforto e da fome saciada. Souza ${ }^{25}$ aponta:

O mundo de alvenaria não estava disposto se abrir para uma aceitação ampla da autora, seja social e literariamente, limitando as possibilidades de acessos de Carolina nesse novo mundo, reduzindo os aspectos estéticos de sua obra ao conteúdo de denúncia social.

É nesse contexto de mudanças e adaptações que Carolina Maria de Jesus é ofuscada com tensões e contradições, afastando o discurso revolucionário da favela e dando vez às críticas políticas e estranhamentos da classe média.

O diário de Carolina é relacionado com o diário de Anne Frank por Sousa ${ }^{26}$, ao fazer a ligação que a autora tem com o período histórico em que vive, além do resgate da voz dos oprimidos e silenciados para o estudo da história social. Silva ${ }^{27}$ compara o falecimento da autora, no

${ }^{25}$ SOUZA, Alessandra Araújo de. Identidades e culturas políticas: Disputas e conflitos nos escritos de Carolina Maria de Jesus. Cadernos Imbondeiro, João Pessoa, v. 1, n. 1, 2010. 20 p. $2 . \quad$ Disponível em <www.ies.ufpb.br/ojs/index.php/ci/article/download/13498/7657>. Acesso em $15 / 08 / 2017$.

${ }^{26}$ SOUSA, Germana Henrique P. de. Memória, Autobiografia e Diário Íntimo: Carolina Maria de Jesus: Escrita íntima e narrativa de Vida. Originada na Tese de Doutorado, UnB. Quadrant, Montpellier, v. 24, p. 299-313, 2007. Disponível em http://repositorio.unb.br/bitstream/10482/9169/1/CAPITULO_MemoriaAutobiografia Diario.pdf. Acesso em 17/05/2015.

${ }^{27}$ SILVA, José Carlos Gomes da. História de vida, produção literária e trajetórias urbanas da escritora negra Carolina Maria de Jesus. $26^{\mathrm{a}}$. REUNIÃO BRASILEIRA $\mathrm{DE}$

ANTROPOLOGIA, 2007.

Disponível em Revista Vernáculo n. ${ }^{\circ} 41$ - primeiro semestre $/ 2018$ 
anonimato e em condições de pobreza, aos de outros escritores negros como Augusto dos Anjos, Cruz e Souza e Lima Barreto, marcados pela tragédia pessoal e reconhecimento público fugaz. O mesmo autor afirma que, na perspectiva mercadológica, a escritora havia se tornado uma espécie de "produto gasto", depois do sucesso do primeiro livro. As poucas informações sobre a nova experiência de vida passaram a ser veiculadas em reportagens esporádicas, quase sempre ofensivas, que reforçavam a imagem de escritora pessoalmente fracassada. Moreira ${ }^{28}$ justifica a atribuição de um papel social muito diferente daquele a que estava habituada como um elemento que incomodou Carolina Maria de Jesus - inclusive a perda do status de "voz das minorias", em meio ao fim do populismo.

No que diz respeito ao estudo da obra de Carolina nos dias atuais, Liebig $^{29}$ traz o enfoque de suas pesquisas: o descaso com que a escritora foi e ainda é tratada no Brasil. Enquanto as suas obras e a sua memória são motivo de análise por parte de diversas disciplinas nos Estados Unidos, alguns professores de Literatura ou Sociologia por aqui sequer as conhecem. Sua produção pós-Quarto de Despejo teve pouca

<http://www.abant.org.br/conteudo/ANAIS/CD_Virtual_26_RBA/grupos_de_trabalho /trabalhos/GT\%2007/jose\%20silva.pdf >. Acesso em 19/05/2015.

${ }^{28}$ MOREIRA, Daniel da Silva. Reconstruir-se em texto: práticas de arquivamento e resistência no Diário de Bitita, de Carolina Maria de Jesus. Estação Literária, vagãovolume 3, p. 64-73, 2009. Disponível em <http://www.uel.br/pos/letras/EL/vagao/EL3Art6.pdf>. Acesso em 20/08/2017.

${ }^{29}$ LIEBIG, Sueli Meira. Redescobrindo Carolina Maria de Jesus, Cidadã do Mundo. Anais do XIV Seminário Nacional Mulher e Literatura / V Seminário Internacional Mulher e Literatura, 2011, Brasília-DF, p. 2295-2306. Disponível em <http://docplayer.com.br/23283304-Redescobrindo-carolina-maria-de-jesuscidada-do-mundo.html>. Acesso em 16/05/2015.

Revista Vernáculo n. ${ }^{\circ} 41$ - primeiro semestre /2018

ISSN 2317-4021 
repercussão no mundo literário, tampouco foi objeto de estudo da crítica nacional, apesar de terem sido editados em outros países, como Diário de Bitita $^{30}$, publicado primeiro na França, em 1982 - obra póstuma.

O Diário de Bitita é apresentado ao Brasil apenas em 1986, sem enfoques acadêmicos ou críticos. Voltado para as memórias de infância e adolescência, a escrita de Carolina difere muito em sua estruturação e gramática, como a separação em capítulos, por exemplo, não datados e com temas claros. No entanto, a leitura dessa obra é, de certo modo, introdutória e esclarecedora para algumas atitudes apresentadas em Quarto de Despejo, como a relação com a mãe e o avô; a percepção tenra de que o homem é "superior" à mulher pela sua força de trabalho; os sentimentos que a fome lhe trazia; e a vontade de mudança de vida. Lembranças cunhadas como obra de ficção brasileira e que se perderam numa sociedade ainda cega para os oprimidos.

O que aconteceu com toda admiração por uma mulher negra, favelada e pobre que relatou as dificuldades em viver à margem da sociedade? Será que a elite teve medo de decair sobre as críticas ao seu poder e descaso social com os menos favorecidos? Mas, aliás, por que Carolina Maria de Jesus nos é de tanta importância, se ela morreu anônima e fracassada?

${ }^{30}$ JESUS, Carolina Maria de. Diário de Bitita. Rio de Janeiro: Nova Fronteira, 1986. $203 \mathrm{p}$.

Revista Vernáculo n. ${ }^{\circ} 41$ - primeiro semestre /2018

ISSN 2317-4021 
Moacir Gadotti ${ }^{31}$ discorre que a esperança de uma educação de melhor qualidade está nas mãos da sociedade, na formação para uma cidadania ativa, na qual o conhecimento é poder e representa um modo de romper com as múltiplas alienações. É essa educação transformadora que podemos relacionar com a história de Carolina e as temáticas que aborda. Mas o problema está fundamentado num sistema econômico ideológico que a própria escola contribui para difundir (como a seleção dos mais "aptos" por meio de testes e avaliações, por exemplo). É preciso colocar o conhecimento acumulado, inclusive de lutas e resistências, em favor da realidade concreta, que apresenta contradições - semelhantes às de Carolina -, e promover mudanças. É só assim que a população, em especial a de classe baixa, terá acesso ao mundo da crítica, do enfrentamento necessário à superação da ideologia dominante historicamente perpetuada pelas vias educacionais: formação da elite e formação para o mercado de trabalho, sem consciência crítica.

Retomamos, por fim, a dedicatória que Paulo Freire apresenta em Pedagogia do Oprimido $^{32}$, que tem uma incrível relação à fala anterior: "Aos esfarrapados do mundo e aos que neles se descobrem e, assim descobrindo-se, com eles sofrem, mas, sobretudo, com eles lutam". $\quad$ Freire traduz o que ele experimentou na convivência com

${ }^{31}$ GADOTTI, Moacir. Educação Brasileira Contemporânea: Desafios do Ensino Básico. Acervo do Centro de Referência Paulo Freire. Disponível em <http://acervo.paulofreire.org/xmlui/bitstream/handle/7891/3393/FPF_PTPF_01_0416 .pdf>. Acesso em 16/05/2015.

${ }^{32}$ FREIRE, Paulo. Pedagogia do Oprimido. 17. ed. Rio de Janeiro: Paz e Terra, 1987, 107p. p. 12.

Revista Vernáculo n. ${ }^{\circ} 41$ - primeiro semestre /2018

ISSN 2317-4021 
os esfarrapados do mundo - estes são para ele futuro viável de outro mundo, de outra realidade social e cultural, construída sobre princípios de uma nova humanidade regida pela solidariedade e pelo diálogo. Portanto, considera que somente os oprimidos e a força de sua luta contra a situação opressora podem levar a sociedade a reassumir e progredir o processo de humanização, refreado pela dominação da sociedade atual. Ou seja, do mesmo modo que Carolina trouxe à tona as mazelas da favela e obteve repercussão mundial, os oprimidos juntos têm o poder de transformação do mundo: transformação esta dada por meio da Educação.

\section{Referências}

FREIRE, Paulo. Pedagogia do Oprimido. 17. ed. Rio de Janeiro: Paz e Terra, 1987. 107p.

GADOTTI, Moacir. Educação Brasileira Contemporânea: Desafios do Ensino Básico. Acervo do Centro de Referência Paulo Freire. Disponível em $<$ http://acervo.paulofreire.org/xmlui/bitstream/handle/7891/3393/FPF_PTPF_ 01_0416.pdf>. Acesso em 16/05/2015.

JESUS, Carolina Maria de. Casa de Alvenaria: Diário de uma ex-favelada. São Paulo: Francisco Alves, 1961. 183p.

Diário de Bitita. Rio de Janeiro: Nova Fronteira, 1986. 203p.

Quarto de despejo: Diário de uma Favelada. São Paulo: Ática, 1995. 173p.

LIEBIG, Sueli Meira. Redescobrindo Carolina Maria de Jesus, Cidadã do Mundo. Anais do XIV Seminário Nacional Mulher e Literatura / V Seminário Internacional Mulher e Literatura, 2011, Brasília-DF, p. 2295- 
2306. Disponível em <http://docplayer.com.br/23283304-Redescobrindocarolina-maria-de-jesus-cidada-do-mundo.html >. Acesso em 16/05/2015.

MEIHY, José Carlos Sebe Bom. Carolina Maria de Jesus: emblema do silêncio. Revista USP, São Paulo (37): 82-91, Março/Maio 1998. Disponível em <http://www.usp.br/revistausp/37/08-josecarlos.pdf>. Acesso em $17 / 05 / 2015$.

MOREIRA, Daniel da Silva. Reconstruir-se em texto: práticas de arquivamento e resistência no Diário de Bitita, de Carolina Maria de Jesus. Estação Literária, vagão-volume 3, p. 64-73. 2009. Disponível em <http://www.uel.br/pos/letras/EL/vagao/EL3Art6.pdf>. Acesso em 20/08/2017.

SANTOS, Gláucia. A intelectualidade de Carolina Maria de Jesus por meio de sua obra "Quarto de Despejo". Centro Universitário de Patos de Minas. Pergaminho (5): 59-68, dez. 2014. Disponível em <http://pergaminho.unipam.edu.br/documents/43440/599489/A+intelectualida de+de+Carolina++Maria+de+Jesus+por+meio+de+sua+obra++_Quarto+de+D espejo_.pdf>. Acesso em 18/04/2015.

SANTOS, Lara Gabriella Alves dos; BORGES, Valdeci Rezende. Quarto de Despejo: o espaço na obra de Carolina de Jesus. Universidade Federal de Goiás. Anais do SILEL. Volume 3, Número 1. Uberlândia: EDUFU, 2013. Disponível em <http://www.ileel.ufu.br/anaisdosilel/wpcontent/uploads/2014/04/silel2013_15 45.pdf $>$. Acesso em 13/04/2015.

SANTOS, Marcela Ernesto dos. Autobiografia feminina: a identidade e o preconceito nas memórias de Carolina Maria de Jesus e Maya Angelou. Revista Iluminart, IFSP, v. 1, n. 4, Sertãozinho, abril de 2010. p. 12-20. Disponível em <https://repositorio.unesp.br/handle/11449/94065>. Acesso em 10/08/2017.

SILVA, José Carlos Gomes da. História de vida, produção literária e trajetórias urbanas da escritora negra Carolina Maria de Jesus. 26 ${ }^{\mathrm{a}}$. REUNIÃO BRASILEIRA DE ANTROPOLOGIA, 2007. Disponível em <http://www.abant.org.br/conteudo/ANAIS/CD_Virtual_26_RBA/grupos_de_ trabalho/trabalhos/GT\%2007/jose\%20silva.pdf >. Acesso em 19/05/2015.

Revista Vernáculo n. ${ }^{\circ} 41$ - primeiro semestre /2018

ISSN 2317-4021 
SOUSA, Germana Henrique P. de. Memória, Autobiografia e Diário Íntimo: Carolina Maria de Jesus: Escrita íntima e narrativa de Vida. Originada na Tese de Doutorado, UnB. Quadrant, Montpellier, v. 24, p. 299-313, 2007. Disponível em http://repositorio.unb.br/bitstream/10482/9169/1/CAPITULO_MemoriaAutobi ografiaDiario.pdf. Acesso em 17/05/2015.

SOUZA, Alessandra Araújo de. Identidades e culturas políticas: Disputas e conflitos nos escritos de Carolina Maria de Jesus. Cadernos Imbondeiro, João Pessoa, v. 1, n. 1, 2010. Disponível em <www.ies.ufpb.br/ojs/index.php/ci/article/download/13498/7657>. Acesso em $15 / 08 / 2017$.

ZINANI, Cecil Jeanine Albert. Produção literária feminina: um caso de literatura marginal. ANTARES, v. 6, n. 12, p. 183-195, jul./dez. 2014. Disponível em <www.ucs.br/etc/revistas/index.php/antares/article/viewFile/3059/1814>. Acesso em 15/08/2017.

.; POLESO, Natalia Borges. Da margem: a mulher escritora e a história da literatura. MÉTIS: história e cultura, v. 9, n. 18, p. 99-112, jul./dez. 2010.

Disponível em <www.ucs.br/etc/revistas/index.php/metis/article/viewFile/998/1054>. Acesso em 15/08/2017.

Recebido em 02/02/2017, aceito para publicação em 02/09/2017.

Revista Vernáculo n. ${ }^{\circ} 41$ - primeiro semestre /2018

ISSN 2317-4021 